\title{
Methodological and Theoretical Considerations regarding Informality on the Labor Market
}

\author{
Cristian MARINESCU ${ }^{1}$ \\ Ileana VALIMĂREANU (MIRCIOI) ${ }^{2}$
}

\begin{abstract}
Since the 1970s when the term "informality" has penetrated into economic theory by designating everything that is not subject to the legal regulations of a state until today, the concept of informality has evolved from "simple business activities carried out by the poor population of economies in development "and up to the concept of" informal employment ", approached from the point of view of jobs or workers, and the" informal employment "approach taken from the perspective of the employer.

Segmentation of the formal and informal workforce market is a specific feature of any labor market, whether we are talking about a labor market in a developed economy or one from a developing economy, with the difference that the motivation that pushes individuals towards informality is different, namely the instinct of survival in the developing economy and the "animal spirits" that Keynes himself spoke in developed economies.

Informality can be considered as a consequence of the transition period to a market economy in the case of the countries that have undergone this transformation or even a consequence of capitalism in developed countries.

Labor market informality is a reality recognized today by the entire scientific community, but still little understood, being a phenomenon that sometimes seems so natural and sometimes transcends our rational understanding.

For this reason, there is a need for a better theorization of the concept of "informality" in order to be able to correctly quantify it and thus to have a true image of a dual economy: formal / informal.
\end{abstract}

Keywords: labor market, formal, informal, employment

JEL classification: J20, J21, J22

DOI: $10.24818 / \mathrm{RMCl} .2018 .1 .54$

\section{Defining "formal" and "informal"}

"Formal" is a rule, an idea of everything that must be universal in a society. The dominant form of the 20th century was that of bureaucracy and, more precisely,

${ }^{1}$ Cristian Marinescu, Romanian Court of Accounts, Email:

cristian.marinescu@macroeconomie.ro

${ }^{2}$ Ileana Valimăreanu, Institute for Doctoral Studies, Business Administration PhD

Programme, Bucharest University of Economic Studies, Email: ileanamircioi@gmail.com

Review of International Comparative Management $\quad$ Volume 19, Issue 1, March $2018 \quad 54$ 
of national bureaucracy, and that since the society as a whole became identifiable with the nation state. As the bureaucracy developed and the society became overregulated, this form of organization began to be considered a weakness of the neo-liberal capitalist economy under the conditions of digital media revolution in recent years (Hart, 2006).

"Form" is an idea whose origins lie in the mind. Form is the rule, it is universal, which remains unchanged within a variable. It is predictable and easy to recognize. Hart gives us, in this regard, the example of a bird atlas where no species with a photograph of each particular bird will be illustrated as it may not accurately embody the image of that species in the sense that it may have a broken leg or a distinct color, which would rather be caricature than the image of a bird species. This shows why Plato's idealist philosophers have said that the general idea of something is much more real than the thing itself, Hegel even demonstrating in his "Science of Logic" the error in considering the idea as reality (Hart, 2006).

Speaking of "rules," Kant states, "Everything in nature, both in the living world and in the living world, happens by the rules even if we do not always know them. Rain falls under the laws of gravity, and the movement of animals is also done according to rules. The fish in the water, the bird in the air moves by the rules. Generally, all nature is nothing but a chain of phenomena subject to rules, and nowhere is there any irregularity. When we think of such a thing, then we can only say that the rules are not known to us "(Kant, 1985, p. 64).

The formal, according to Hart, is the presumptive constant within a variable. It is assumed that what is considered to be variable, that is, the rule, rarely occurs in practice. Formally, it defines what is regulated, predictable, recognizable and reproducible, and what is intrinsic to all social behaviors to a certain extent. When we identify something as informal is because it fails to fit into an existing model. The consequence of the economic analysis is obvious in this case. "Formal economy" is the result of everything that conforms to existing regulations in a modern society, and the "informal economy" refers to everything that does not involve regulation, namely what is illegitimate, unstable, unprepared, which is really invisible. In reality, however, those who carry out informal activities consider that they have a formal basis (verbal agreements or written agreements), but these formalities are more rigid and less relevant than those prescribed by law. This means that informality exists only in the eyes of the non-phenomenon, because the informal economy does not exist in an empirical sense, but it is only a way of expressing the contrast of those phenomena that we imagine to constitute the orthodox core of the economy (Hart, 1973, pp. 61-89).

The "formal sector" is also an idea, a bunch of people, things and activities, but we do not have to confuse the category with the reality that identifies it. What makes something formal is its conformity with an idea or rule. "Thus, formal dressing in some societies means that men dress like penguins, but women are free to wear extravagant things that fit them. Men all look the same, and for that they adopt a uniform that cancels their individuality. Formality provides a category of 
people with universal traits, it assumes that the elements of a category are the same. What makes informal dress is precisely the absence of such a rule "(Hart, 2006).

From our point of view, empirically, informality does not exist as such, being merely a way of expressing the lack of formality, being the contrast of those economic principles considered as part of the Orthodox nucleus of economic science.

This explanation of informality could be associated with the metaphysical definition of "evil", which, in the ontological philosophical conception, is considered a lack of good.

Evil can be defined as a lack of a thing, as it is not a substance because it has no positive nature, but the loss of good has been called evil. Evil is not nature, it is what is contrary to nature; it does not exist by itself but lives in something else.

Augustinian Theodics promotes the idea of the negative or deprivation nature of evil. According to St. Augustine, "evil - either a bad will, or a pain, or a certain disturbance or corruption of nature - was not therefore instituted by God, but is the distortion of something inherently good" (Hick, 2010, p. 78).

According to Toma of Aquino, "evil is a lack of good that has taken place and must be detained. The evil has nothing but an accident, and in this sense good is the cause of evil ... Taken in a private sense, the absence of good is called evil ... Evil, even as privation, corrupts good because it itself constitutes corruption or deprivation of good. "(Toma in Aquino, 2009, pp. 435-447).

In the same way (not having its own existence) the "negative" to "substance" or "false" to "truth" is also interpreted in the Hegelian sense.

"The inequality established in the consciousness between" $\mathrm{Eu}$ "and" substance "- which is the object of it, is its difference, the negative in general. Truth and falsehood belong to determined thoughts, which, without movement, pass as their own essences, these being diametrically opposed, without being in communion with each other. Truth is not self-evident and must not be taken as it is. Also, there is nothing false as there is no harm. Evil and false are not as bad as the devil, for if they were so, they would be just private subjects, while in fact evil and falsehood are only universal. "(Hegel, 2010, pp. 28, 29).

"Formal" and "informal" appear to be separate concepts because of the use of the term "sector". It gives the impression that the two are in different places, such as agriculture, in production, when both forms, both bureaucratic and informal, contain the formal / informal duality both within and between themselves. The need to link the two sectors stems from a widespread perception that the relationship between them is at the moment in a class struggle between bureaucracy and individuals. But this was not the idea of bureaucracy. It was invented as part of democracy to give citizens the opportunity to exercise their rights equally within society. At this point, however, the bureaucracy seen as "the power of state authorities in front of individuals" has come to be considered a vice of democracy, seen as "the power of the people within a society." Over-regulation within a society makes the power of individuals fall into that society and their rights are restricted by the one who should facilitate the exercise of the rights of individuals, namely the 
state. For this reason, individuals try to escape from the formal area, opting for the informal zone of society (Hart, 2006).

\section{The terminology of "informality"}

There is no single and clear definition of the concept of "informality", economists associating this term with various aspects, in most cases, they denote something negative, such as: socially unprotected workers who do not benefit from social security, poor productivity, unfair competition, excessive legislative regulations, non-payment of taxes to the state budget (tax evasion), "underground" economy, "black" work, etc.

Most economists have seen "informality" in quantitative terms, considering it as a sector where productivity is low, labor gains are low, commercial activities are taking place without the benefit of modern technology in the formal sector, but there are authors Hart, 2006) that interpreted "informality" in terms of the absence or presence of "bureaucratic" form.

The term "informality" can be attributed to Keith Hart, who first used this concept in the early 1970s (and not necessarily in a pejorative sense) in a paper in which he talked about urban occupation in Ghana. Hart believes that a lack of knowledge of the informal sector makes it vulnerable, as a "racial taboo where analysts will design their own opinions and concerns" (Hart, 1973, pp. 61-89).

Most companies operate under bureaucratic regulations and can be monitored through various surveys, thus constituting the "modern sector" of the economy, and the rest, those that can not be monitored, are considered to be part of the "urban productivity sector weak ", which may also be called the" traditional urban sector "or, more plastic," the reserve army of unoccupied or unemployed people "(Hart, 1973, p. 68).

Informality can be seen as a result of voluntary "exclusion" or "exit" from the labor market according to the factors that cause workers to leave the formal sector of the labor market. Thus, informality arises as a result of "exclusion" from the market when the formal sector does not offer enough employment opportunities, bureaucracy is excessive and blocks access to formality or when costs to become "formal" are high. Also, informality can also be interpreted as a result of "exit" from the market when formal employment does not bring sufficient benefits to workers or when they do not trust public institutions. In this case, possible "formal" workers prefer to remain freelancers or be their own employers in informal activities (Perry, Maloney et al., 2007).

When deciding whether to opt for the formal sector of the economy or the informal sector, most workers, families or even firms make a cost-benefit analysis of the two sectors of the economy, taking into account, on the one hand, the high costs of the formal sector generated by state taxes, excessive regulations, the bureaucratic system and the rest of the cost of entry into the formal segment of the economy, but also the benefits of this sector, such as high returns, access to social contributions for employees, access to credit both on the part of workers and firms 
and on the other hand the costs and benefits of the informal sector generated by poor productivity and productivity, lack of access to social security, credit, the risk of identification by the competent state bodies and sanctioning according to the legal provisions, but also the advantage financially generated by an additional profit due to contributions in the form of taxes and taxes that workers and firms in the informal sector of the economy do not pay to the state budget anymore.

From a terminological point of view, the "informality" of labor is encountered in economic theory under several names among which the most commonly used are: Informal Sector (Hart Keith, 1973); Undeclared work (European Commission, 1998); Informal Economy (BIM, 2002); Employment in the informal sector and informal employment (ILO, 1993/2003); Occupy invisible or hidden (OECD, 2004).

Also, if we refer to "informality" in a general sense, literature also uses other concepts to define it, such as: underground economy, shadow economy; dual economy; tax evasion (as a practice of informality).

\section{Informality seen as "informal sector"}

The term "informal sector" became known in the 1970s as a concept that defines economic activities that take place outside the organizational framework of the public or private sector. It first appeared as a response to the proliferation of occasional or self-employed work in the cities of underdeveloped countries, and later this concept was also used in developed societies such as the UK, along with other adjectives such as underground economy, hidden economy, black work. However, empirical references to the informal sector remain elusive, ranging from "publicly affected public finances in Zaire and self-employed workers in London's suburbs" (Hart, 2011).

In recent years, the literature has proposed new approaches to formal / informal dualism of the labor market, so that the "formal sector" of the economy is also called the "modern, urban, industrial or good workplace" sector, while " the informal sector "is also referred to as the" traditional sector, agriculture, rural or bad sector "(Field, 2009, p. 4).

\section{Informality seen as "informal sector employment"}

"Employment in the informal sector" of the economy is a concept that appears first used in 1993 in a resolution adopted by the International Labor Office at the 15th International Conference of Labor Statisticians.

According to this resolution, it is recommended to classify informal activities in two categories, namely: on the one hand, informal work carried out by self-employed workers and on the other hand the activities of informal workers or, in other words, the concept of " informality "(Solorzano and del Miguel, 2003, p. 15).

\section{Informalities seen as "undeclared work" and "invisible employment"}


On the chronological line of time, we find the term "undeclared work" introduced by the European Commission in 1998. It regarded undeclared work as "all paid remuneration activities that are mainly legal, but not declared to the state, although the legal regulations of that State requires their declaration. "

A definition close to that of the European Commission is also proposed by the Organization for Economic Co-operation and Development (OECD), which in a 2004 Report uses the term "invisible employment" referring to "work that, although it is not unlawful in itself, has not been declared to any state authority "(OECD, 2004).

\section{Informality seen as "informal economy"}

In order to include all of the above-mentioned categories of informalities in the 2002 International Labor Conference, the term 'informal economy' was used, and it is preferred to the term 'informal sector' since it includes both informal and nonworks informally: "The informal economy refers to all economic activities carried out by workers and economic units which, in law or in fact, are not regulated or are too little formally regulated" (BIM, 2002).

\section{Informality seen as "informal employment"}

The terminology of "informality" is further developed, so that in 2003 there is a new term of informal work, namely "informal employment". This new term was proposed by the International Labor Office at the 17th International Conference of Labor Statisticians.

If in 1993, at the 15th International Conference of Labor Statisticians, the term "informal sector employment" was proposed, defining informal work in terms of the decarification of the production units in which the economic activity takes place ( approach in the perspective of production or enterprise), the term "informal employment" appears in 2003, whereby informal work is defined in terms of the characterization of the employed persons and of their jobs (the approach from the job position of the employee).

\section{Informality seen as "underground economy"}

The "underground economy" can be defined as representing all those economic activities that are taken into account when determining the gross national product but are not recorded (Edgar Feige $(1989,1994)$, Schneider (1994a), Frey and Werner (1984) Lubell (1991)].

Another definition of the underground economy is that given by Philip Smith, which defines it as "the production of goods and services on the market, whether produced legally or illegally and not taken into account in the official estimates of gross domestic product" (Smith , 1994, p. 18).

Among the causes that have led to the growth of the underground economy can be mentioned (Schneider and Enste, 2000, pp. 82-90):

* Increase in tax burden due to increased taxes and social contributions; 
* Increase of legal regulations in the formal, official economy and especially in the labor market;

* Reduced weekly working time;

* Early retirement (anticipated);

* Unemployment;

* Diminishing civic attitude as well as trust in public institutions combined with a decrease in tax morality.

In Dinu's opinion, another cause of the underground economy can be considered as speculation: "The most advanced form of the new economic order arose when the economic preference for fictitious money gave the tone to the internationalized financial market. The significant result was that financial speculation claimed to be a yielding activity and the autonomy of the monetary economy was institutionalized. The historical end of the rupture is represented by the elimination of the gold standard, the last methodological formula that tried to preserve the balance between the real economy and the monetary economy. It is the terminal from which the economic crises started exclusively from the territory of the monetary economy. From that point on, economic rationality was judged by rules different from previous ones, stemming from common sense. The speculation contaminated the real economy with the propensity to look for rent, and in the market it supported the extension of the underground economy "(Dinu, 2010, p. 325).

\section{Informality seen as a "dual economy"}

More recent studies use the term "dual economy" to define informality (Dinga, 2009). Dinga sees the dual economy as the response of the economy to the way a national state is governed, as it complements and subverts the formal economy: "Dual economy is a permanent companion of the primary economy, and primarily because of the functions it performs in completing or replacing the primary economy. Dual economy is therefore inevitable. What is important is not its liquidation, otherwise it is impossible, but its understanding, monitoring, use and restriction within functional limits. The dual economy is a response of the economic system to the government management act. It could be said that the more the dual economy is wider, the weaker government management (Dinga, 2009, p. 316).

Dinga explains the use of the term "dual economy" instead of "underground economy" by the fact that the term "underground economy" has a totally unnoticed connotation of economy, while the notion of "dual economy" also includes incomplete observability or observability . The notion of "dual economy" is also considered more appropriate for the fact that this concept includes both the concepts of hidden economy or the shadow economy and the notions of "black economy" or "gray economy" (Dinga, 2009, p. 299).

Another definition of the dual economy is given by Hart who, referring to the dual nature of the economy, considers that certain activities and societies are formal in the sense that they are carried out in a legal framework and are subject to 
special regulations, while others "Take place behind the actual regulations of the state" (Hart, 2001).

\section{Informality seen as "evasion"}

In any economy, irrespective of its degree of development, there are three categories of participants in economic life, namely: the "state" - which appears in its dual quality, respectively the market regulator, but also the consumer or service provider; "Firms" - in their capacity as profit-oriented economic agents, but also consumers and "individuals" - taken individually or as households (households) that appear, in particular, as consumers. Individuals can participate in economic life and as economic agents when conducting economic activities. Among the three categories of actors in the economic markets there are interdependence relationships, especially between individuals / firms and the state, as a market regulator.

Informality occurs in the relationship between the "state" as a regulator and the other participants in the economic life, namely "firms and individuals" when the latter act as traders and do not comply with the legal norms established by the "state". In general, businesses and individuals, before leaving the formal sector of the economy and entering the informal sector, make a cost-benefit analysis taking into account the financial benefits they gain by opting for informality but also the risks they are facing leaving the formal sector of the economy.

In the literature, there are considered three types of relations between individuals / firms and the state, namely: opportunistic evasion; defensive evasion and exclusion; passive evasion and irrelevance (Perry, Maloney et al., 2007, pp. 23-25).

"Opportunistic evasion" is considered to be the informal sector when it eludes the legal norms in the following forms: evasion of the taxes and taxes to the state by non-observance of the legal provisions; illegal, when engaging in nonsanctionable activities; unprotected when workers, especially from developing countries, are not protected by labor law. Companies doing this kind of tax evasion by circumventing labor law create implicitly a dual labor market where their own employees would prefer to choose that side of the market that offers them social protection but accept for a certain time to be in a lower job, represented by the informal labor market segment.

"Defensive Evasion and Exclusion". It is known in the literature that the state is not the best administrator and does not always do its job according to the economy's principles or economists' ideals, and this affects the other participants in economic life, individuals or economic agents. The measures that the state adopts oscillate, most of the times, from a too loose system to too stringent measures to regulate some areas of activity, and also from lax taxation to an oppressive taxing force taxpayers get into a defensive evasion.

Thus, high registration costs, as well as busy legislation for a taxpayer to formally operate, make many businesses preference for informality.

"Passive evasion and state irrelevance". In their studies, some economists (Hart, Geertz) have discovered that many of the small entrepreneurs are not 
considered to be part of the modern, formal economy, since they do not need the services offered by the state to do their job, reason for whom they prefer to remain in the informal economy, while others (Bentolila, Ichino) consider that the "safety net" offered by the informal sector in southern Europe, taking on the shocks of formal employment, is even more important than protection legal employment of unemployed people through unemployment benefits in northern Europe.

\section{Conclusions}

From what is presented in this paper on the terminology of "informality" one can conclude that there is no single definition of the concept of "informality". Some economists have seen "informality" in quantitative terms, considering it as a sector where productivity is low, labor earnings are low, business activities are taking place without the benefit of modern technology in the formal sector, and other economists have interpreted "Informality" from the point of view of the absence or presence of the "bureaucratic" form, but most economists associate this term with various aspects, in most cases, they denote something negative, such as: socially unprotected workers social security, poor productivity, unfair competition, excessive legislative regulations, failure to pay taxes to the state budget (tax evasion), "underground" economy, "black" work, etc.

From the terminological point of view, the "informality" of labor is encountered in economic theory under several names, among which the most commonly used are: Informal sector, undeclared work, informal economy, informal employment, informal employment, invisible or hidden occupation, and if we refer to "informality" in a general sense, the literature also uses other concepts to define it, such as: underground economy, shadow economy; dual economy; tax evasion (as a practice of informality).

\section{References}

1. Communication of the Commission on Undeclared Work, 7 April 1998;

2. Dinga Emil, 2009, "Studii de Economie. Contribuții de analiză logică, epistemologică și metodologică", Editura Economică, București;

3. Dinga Emil, 2008, "Consideratii teoretice privind evaziunea fiscală vs frauda fiscală", Studii Financiare - Abordări teoretice şi modelare, vol. 12, issue 4, pages 20-50;

4. Dinu Marin, Marinaş Marius, Socol Cristian, Socol Aura, 2011, „Testing of the Okuns Law in Romania", Economic Computation and Economic Cybernetics Studies and Research Journal no. 1/2011, vol. 45, pp. 5-20;

5. Dinu Marin, 2010, "Economia de Dicționar. Exerciții de îndemânare epistemică", Editura Economică;

6. Feige Edgar, 1994, "The Underground Economy and the Currency Enigma", Public Finance Publiques, vol. 49 pages 119-36; 
7. Feige Edgar, 1989, "The Underground Economies: Tax Evasion and Information Distortion", Cambridge University Press;

8. Fields Gary S., 1975, "Rural-Urban Migration, Urban Unemployment and Underemployment, and Job Search Activity in LDC's," Journal of Development Economics 2: 165-188;

9. Fields Gary S, 2008, "Segmented Labour Market models in developing countries", Cornell University ILR School, paper 162;

10. Frey B., Werner P., 1984, "The hidden economy: State and prospects for measurement", Review of Income and Wealth, Volume 30, Issue 1, pp. 1-23, March 1984;

11. Frey B. and Feld L., 2002, "Deterrence and Morale in Taxation: An Empirical Analysis", Working Paper 760, Center for Economic Studies and the Ifo Institute, Munich;.

12. Hart Keith, 1973, "Informal income opportunities and urban employment in Ghana", Journal of Modern African Studies 11, 61-89;

13. Hart Keith, 2001, "Money in an Unequal World", Texere Books;

14. Hart Keith, 2006, "Bureaucratic form and the informal economy", In linking the Formal and Informal Economy: Concepts and Policies, edited by Basudeb Guha Khasnobis, Ravi Kanbur and Elinor Ostrom, Oxford University Press;

15. Hart Keith, 2011, "Informal economy", The Memory Bank;

16. Hegel, 2010, "Fenomenologia spiritului", Editura Univers Enciclopedic Gold;

17. Hick H. John, 2010, "Filosofia religiei", Editura Herald, București;

18. ILO, 2002, "Decent Work and the informal economy", Report of the DirectorGeneral presented to the 90th International Labour Conference, International Labour Office, Geneva;

19. Kant Immanuel, 1985, (1800), "Logica Generală”, Ed. științifică și enciclopedică, București;

20. Lubell Herald, 1991, "The informal sector in the 1980's and 1990's", Paris, OECD;

21. Maloney William F.,2004, "Informality Revisited", World Development no. 32 (7): pp. 1159-78;

22. OECD, 1994, "The Jobs Study. Facts, analysis, strategies", pp. 1-55;

23. OECD, 2004, "Employment Outlook";

24. Perry Guilermo, Maloney William and col., 2007, „Informality: Exit and Exclusion", The World Bank, Washington DC;

25. Schneider Friedrich, 1994, "Measuring the size and development of the shadow economy. Can the causes be found and the obstacles be overcome?" in: Brandstaetter, Hermann, and Güth, Werner (eds.): Essays on Economic Psychology, Berlin, Heidelberg, Springer Publishing Company, pp. 193-212;

26. Schneider Friedrich, Enste Dominik, 2000, „Shadow Economies: Size, Causes and Consequences", Journal of Economic Literature, 38 (1), 77-114;

27. Smith Philip, 1994, "Assessing the Size of the Underground Economy: the Statistics Canada Perspective", Canadian Economic Observer, May, Statistics Canada, Catalogue No. 11-010; 
28. Solorzano Juan Diego, Cid del Miguel, 2003, "Decent work and the informal economy in central America", Working Paper no. 7, ILO Geneva;

29. Toma din Aquino, 2009, "Summa Theologica", Editura Polirom, Iași, 